\title{
Induction of Dormancy in Nondormant Seeds
}

\begin{abstract}
Anwar A. Khan
Department of Horticultural Sciences, New York State Agricultural Experiment Station, Cornell University, Geneva, NY 14456

Additional index words. gibberellin biosynthesis inhibitors, dormancy induction, dormancy release, germination inhibition, growth retardants, abscisic acid, tetcyclacis

Abstract. A gibberellic acid (GA) biosynthesis inhibitor, tetcyclacis, induced dormancy in nondormant seeds of lettuce (Lactuca sativa L.), tomato (Lycopersicon esculentum Mill.), pepper (Capsicum annuum L.), carrot [Daucus carota var. sativus (Hoffn.)], onion (Allium cepa L.), celery (Apium graveolens L.), and impatiens (Impatiens novette ), as most of the seeds failed to germinate after washing under conditions that permitted germination before dormancy induction. In lettuce seeds, tetcyclacis and paclobutrazol were more effective in inhibiting germination in light than in darkness. A 16to 24-h soak treatment with tetcyclacis was sufficient to induce dormancy in nearly all seeds. Tetcyclacis failed to induce dormancy if applied after $6 \mathrm{~h}$ presoak in water. Dormancy induced by tetcyclacis was released by GA $\mathbf{A}_{4+7}\left(\mathrm{a}_{\text {mixture of }}\right.$ gibberellin $A_{4}$ and $A_{7}$ ), light, and moist-chilling treatments. When $\mathbf{G A}_{4+7}$ was applied with tetcyclacis, dormancy induction was prevented under both favorable, e.g., $25 \mathrm{C}$, and unfavorable, e.g., 5C, or low water potential $(\psi)$, germination conditions. Unlike tetcyclacis, abscisic acid (ABA) failed to induce dormancy in lettuce seeds. Thermodormancy induction in lettuce seeds at 35C was prevented by fluridone. However, neither ABA nor tetcyclacis countered its effect. Dormancy was also induced in lettuce seeds by ancymidol, flurprimidol, or paclobutrazol. Dormancy induced by tetcyclacis in pepper, tomato, carrot, and onion seeds was released by $\mathbf{G A}_{4+7}$, but not by irradiation or moist-chilling. Chemical names used: 5-(4-chlorophenyl)-3, 4,5,9,10-pentaazatetracyclo $\left[5.4 .10^{2,6} .0^{8,11}\right]$-dodeca-3,9-diene (tetcyclacis); 1-(4-chlorophenyl)4, 4-dimethyl-2-(1H-1, 2, 4-triazole-1-yl )-3-pentanol (paclobutrazol); $\alpha$-cyclopropyl- $\alpha$-(4-methoxyphenyl)- 5-pyrimidine methanol (ancymidol); $\alpha$-(1-methyl)- $\alpha$-[4-(trifluoromethoxy) phenyl]-5-pyrimidine-methanol (flurprimidol); 1-methyl3-phenyl-5-[3-(trifluoromethyl)phenyl]-4 (1H)-pyridinone (fluridone).
\end{abstract}

Growth-retarding compounds such as (2-chloroethyl) trimethylammonium chloride (CCC), 1,1-dimethylpiperidinium chloride (DPC), 2'-isopropyl-4'-(trimethylammonium chloride)5'-methylphenyl piperidine carboxylate (AMO-1618), and tributyl2,4-dichloro-benzylphosphonium chloride (Phosphon D) have been used to reduce stem growth and lodging (Cathey, 1964; Jung and Rademacher, 1983). The mode of action of these growth regulators appears to be related to the inhibition of GA synthesis (before ent- kaurene), as simultaneous application of GA will cancel the growth-retarding effect (Rademacher, 1991). Highly active growth retardants such as ancymidol, tetcyclacis, paclobutrazol, and uniconazol have recently been developed (Izumi et al., 1984; Jung et al. 1980; Lever et al., 1982; Shive and Sisler, 1976) with high specificity for oxidative steps leading from ent-kaurene to ent-kaurenoic acid in the GA biosynthesis pathway (Coolbaugh et al., 1978; Jung and Rademacher, 1983).

Evidence has been presented for the primary role of GA in dormancy control and seed germination (Khan, 1971). Inhibitors of GA biosynthesis, particularly those inhibiting ent-kaurene oxidation, readily inhibit seed germination and the effect is reversed by GA. Gardner (1983) found that ancymidol inhibited the red-light-induced germination of 'Grand Rapids' lettuce seed, which was reversed by $\mathrm{GA}_{3}$, and he suggested that the photoreceptor, phytochrome, might exert its effect on germination via control of GA level. Similarly, Karssen et al. (1989) showed that the lightpromoted germination of Arabidopsis thaliana seeds was inhibited by $10 \mu \mathrm{M}$ tetcyclacis and the effect was reversed by $10 \mu \mathrm{M}$ $\mathrm{GA}_{4+7}$. In another study by Nambara et al. (1991), dark germination

Received for publication 25 Aug. 1993. Accepted for publication 2 Dec. 1993. I gratefully acknowledge the samples of tetcyclacis from Badische Aniline Soda Fabrik, Limburgerhof, Germany; of ancymidol, flurprimidol and fluridone from Eli Lilly and Company, Indianapolis, Indiana; of paclobutrazol from Imperial Chemical Industries Americas, Inc. (ICI), Wilmington, Delaware; and of $\mathrm{GA}_{4+7}$ from ICI, Fernhurst, England. The cost of publishing this paper was defrayed in part by the payment of page charges. Under postal regulations, this paper therefore must be hereby marked advertisement solely to indicate this fact. of mutant seeds of Arabidopsis thaliana was completely inhibited by $10 \mu \mathrm{M}$ uniconazol and the inhibition was reversed by $\mathrm{GA}_{3}$.

Abscisic acid is often implicated in dormancy induction and maintenance (Karssen et al., 1989; Le Page-Degivry and Garello, 1992). In many studies, dormancy release is synonymous with germination (radicle protrusion), as is dormancy induction with germination inhibition. In this study, data show that GA biosynthesis inhibitors, unlike ABA, are capable of inducing dormancy in nondormant seeds of several crops, and that the induced dormancy can be released by $\mathrm{GA}_{4+7}$ and other factors that mimic GA effect, under conditions both favorable and unfavorable for germination. These data reveal that induction, prevention, or release of dormancy can be modulated in the absence of germination.

\section{Materials And Methods}

The following seeds were obtained for this study: lettuce (Lactuca sativa L. cv. Emperor, Garnet, Empress, and Grand Rapids), onion (Allium cepa L. cv. Texas Early Grano), carrot (Daucus carota var. sativus cv. Long Imperator), celery (Apium graveolens L. cv. FM 1218), and tomato (Lycopersicon esculentum Mill.cv. Jackpot) from Ferry-Morse Seed Company, Modesto, Calif.; lettuce (cv. Mesa 659, Montello, and Ithaca) from Harris Moran Seed Company, Rochester, N.Y.; pepper (Capsicum annuит L. cv. California Wonder) from Petoseed Company, Saticoy, Calif.; and impatiens (Impatiens novette) from Zaadunie Research, Enkhuizen, Holland. All seeds were stored at 7C and 28\% relative humidity $(\mathrm{RH})$.

The GA biosynthesis inhibitors (tetcyclacis, paclobutrazol, flurprimidol, and ancymidol), $\mathrm{GA}_{4+7}$, and fluridone were gifts. ( \pm )cis, trans- ABA (Sigma) contained equal amounts of + and $-\mathrm{ABA}$ and the concentrations reported are those for $+\mathrm{ABA}$ (biologically active). Stock solutions of GA synthesis inhibitors and fluridone were made by dissolving the chemicals in small acetone amounts $[0.5 \%(\mathrm{v} / \mathrm{v})]$, and water was added to obtain the needed volume. Final acetone concentration never exceeded $0.25 \%(\mathrm{v} / \mathrm{v})$. At this 
concentration acetone had no inhibitory effect on germination or seedling development. Other chemicals were dissolved directly in water.

To determine if GA biosynthesis inhibitors and ABA induce dormancy, seeds in batches of 200 were soaked in darkness under various conditions and for different periods in $9-\mathrm{cm}$ petri plates on two layers of filter paper (grade 1; Whatman LabSales, Hilsboro, Ore.) moistened with $7 \mathrm{ml}$ of test solutions, prepared in either water or in $-1.2 \mathrm{MPa}(32.6 \mathrm{~g} / 100 \mathrm{ml}$ water) polyethylene glycol 8000 solution. Germination during this initial soak was counted. Nongerminated seeds were washed with excess water on a sintered glass funnel under suction. Seeds were either germinated (in three replicates of 50 seeds each) before or after drying (with forced air to original weight for $2 \mathrm{~h}$ in darkness at 25C) in continuous light ( 8 to $9 \mu \mathrm{mol} \cdot \mathrm{m}^{-2} \cdot \mathrm{s}^{-1}$ ) from cool white fluorescent lamps, or in darkness at $25 \mathrm{C}$, in 5-cm petri plates lined with two layers of filter paper (grade 1; Whatman) moistened with $3 \mathrm{ml}$ water or $\mathrm{GA}_{4+7}$ solution. Failure to germinate in darkness and/or light indicated that dormancy was induced.

To determine if moist-chilling would release the dormancy previously induced by GA biosynthesis inhibitors, dormant seeds ( three replicates of 50 seeds each) were moistened with $3 \mathrm{ml}$ water on two layers of filter paper and chilled at $5 \mathrm{C}$ in the dark. Following moist-chilling, seeds were germinated in darkness at $25 \mathrm{C}$.

To determine the point during imbibition when dormancy is induced by tetcyclacis or ABA, lettuce seeds (in three replicates of 50 seeds each) were imbibed in water in darkness for up to $10 \mathrm{~h}$ before transfer to tetcyclacis or ABA solution for $24 \mathrm{~h}$ in darkness. These seeds were then washed and germinated in water as above.

Manipulations requiring darkness (adding test solution, washing, counting, drying, and transferring seeds) were conducted under a green safe light as described before (Samimy and Khan, 1983). The experiments reported here were repeated two or more times with similar results.

\section{Results}

Effect of GA biosynthesis inhibitors on germination in light and darkness. The GA biosynthesis inhibitor, tetcyclacis, strongly inhibited the germination of nondormant 'Mesa 659' lettuce seeds at $25 \mathrm{C}$ (Fig. 1A). A 50- $\mu \mathrm{M}$ concentration of tetcyclacis was needed for inhibition in the light, compared to $10 \mu \mathrm{M}$ in darkness. Similarly, paclobutrazol at 10 to $100 \mu \mathrm{M}$ was more effective in inhibiting germination in darkness than in light (Fig. 1B). Generally, if the lettuce seed germination remained inhibited for about $24 \mathrm{~h}$ in darkness by an inhibitor at a particular concentration, the seeds were rendered dormant. Differences in responsiveness to tetcyclacis in light and darkness were found also in seeds of impatiens novette (Fig. 2).

Dormancy induction in nondormant lettuce seeds by GA synthesis inhibitors and its relief by $G A_{4+7}$, irradiation, or moistchilling. Dormancy was induced in nondormant 'Montello' lettuce seeds soaked in the dark for $24 \mathrm{~h}$ in $50 \mu \mathrm{M}$ tetcyclacis, as the seeds failed to germinate upon washing and transfer to water in the dark. The induced dormancy was released by irradiation (Fig. 3A) or by $\mathrm{GA}_{4+7}$ (Fig. 3B). A 24-h dark soak in 50 or $100 \mu \mathrm{M}$ ABA failed to induce dormancy as the seeds germinated readily on transfer to water in both light and darkness. The time needed for complete release of dormancy varied among the cultivars (not shown). Dormancy induced by 5 or $50 \mu \mathrm{m}$ tetcyclacis was released to a large extent in various cultivars by irradiation (Table 1), a soak in $1 \mathrm{~mm}$ $\mathrm{GA}_{4+7}$ (Table 2), or by moist-chilling at $5 \mathrm{C}$ (Table 3 ). Following the induction of dormancy with tetcyclacis, lettuce seeds, soaked for up to 10 days in water at $25 \mathrm{C}$, or dried back at $25 \mathrm{C}$ by forced air to original weight, responded fully to dormancy releasing treatments (light, $\mathrm{GA}_{4+7}$ ) (data not shown). Dormancy release resulted in normal seedling development in all cases.

Other GA biosynthesis inhibitors, ancymidol, paclobutrazol, and flurprimidol, also induced dormancy in lettuce seeds (Table 4). As with tetcyclacis, irradiation, $\mathrm{GA}_{4+7}$ treatment, and moist-chilling were effective in releasing dormancy.

A progressively greater degree of dormancy was induced in 'Mesa 659' lettuce seeds, with increasing soaking period in $50 \mu \mathrm{M}$
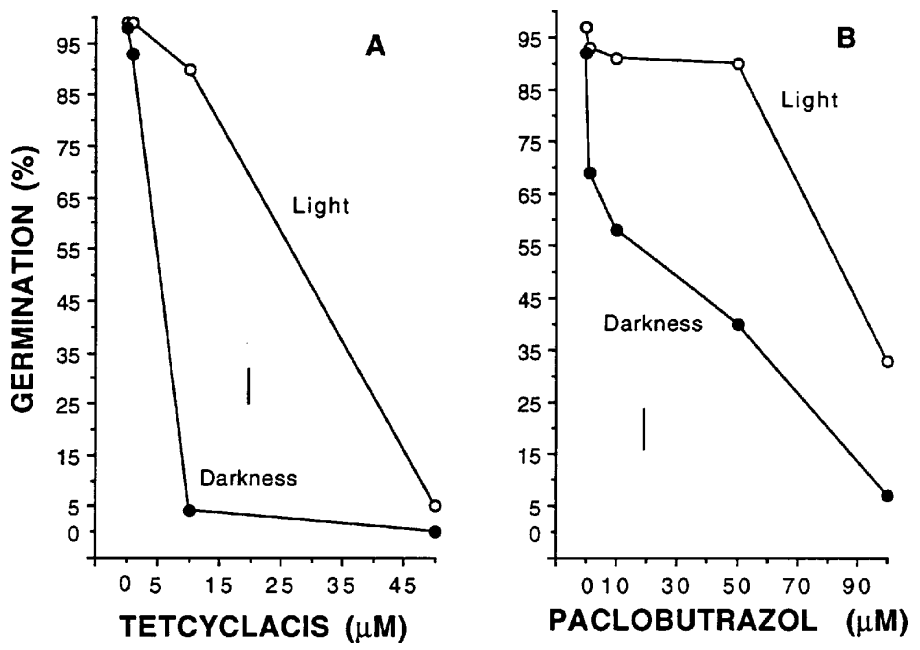

Fig. 1. Effect of (A) tetcyclacis and (B) paclobutrazol on germination of 'Mesa 659' lettuce seeds in light and darkness at $25 \mathrm{C}$. Seeds were germinated for 10 days. Bars in (A) and (B) indicate LSD $_{0.05}$.

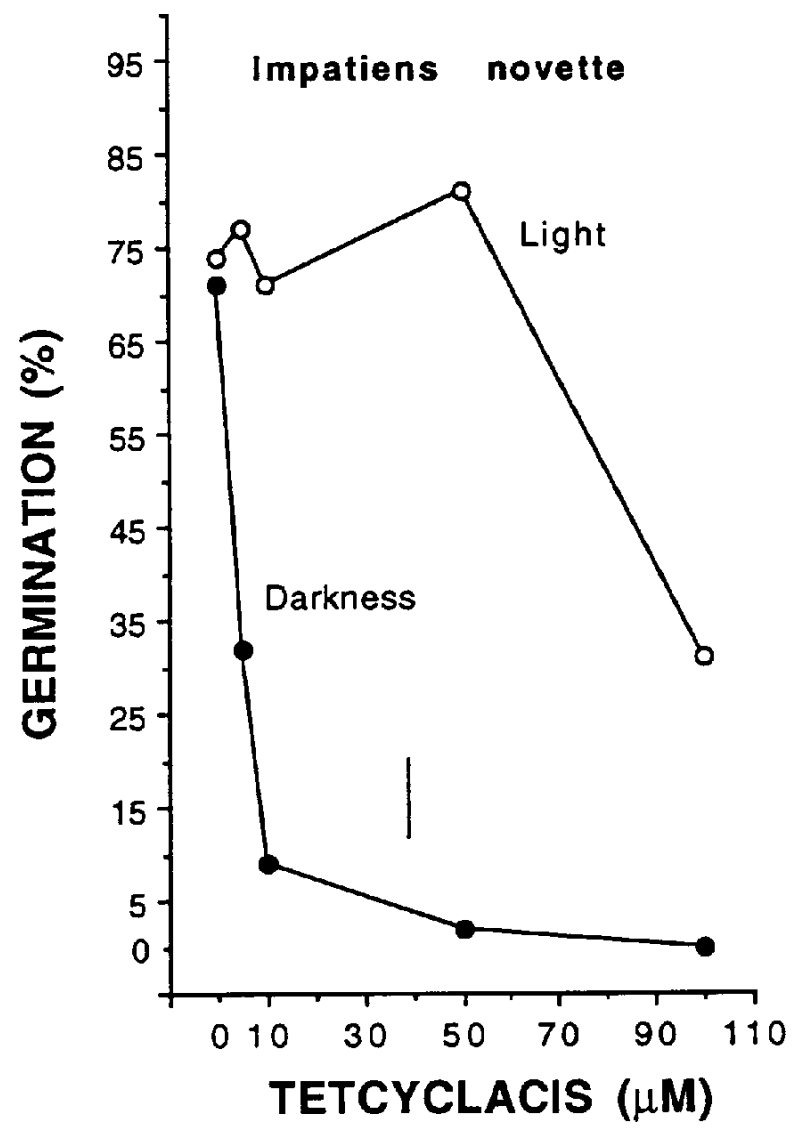

Fig. 2. Effect of tetcyclacis on germination of impatiens seeds in light and darkness at $25 \mathrm{C}$. Seeds were germinated for 10 days. Bar indicates $\mathrm{LSD}_{0.05}$. 


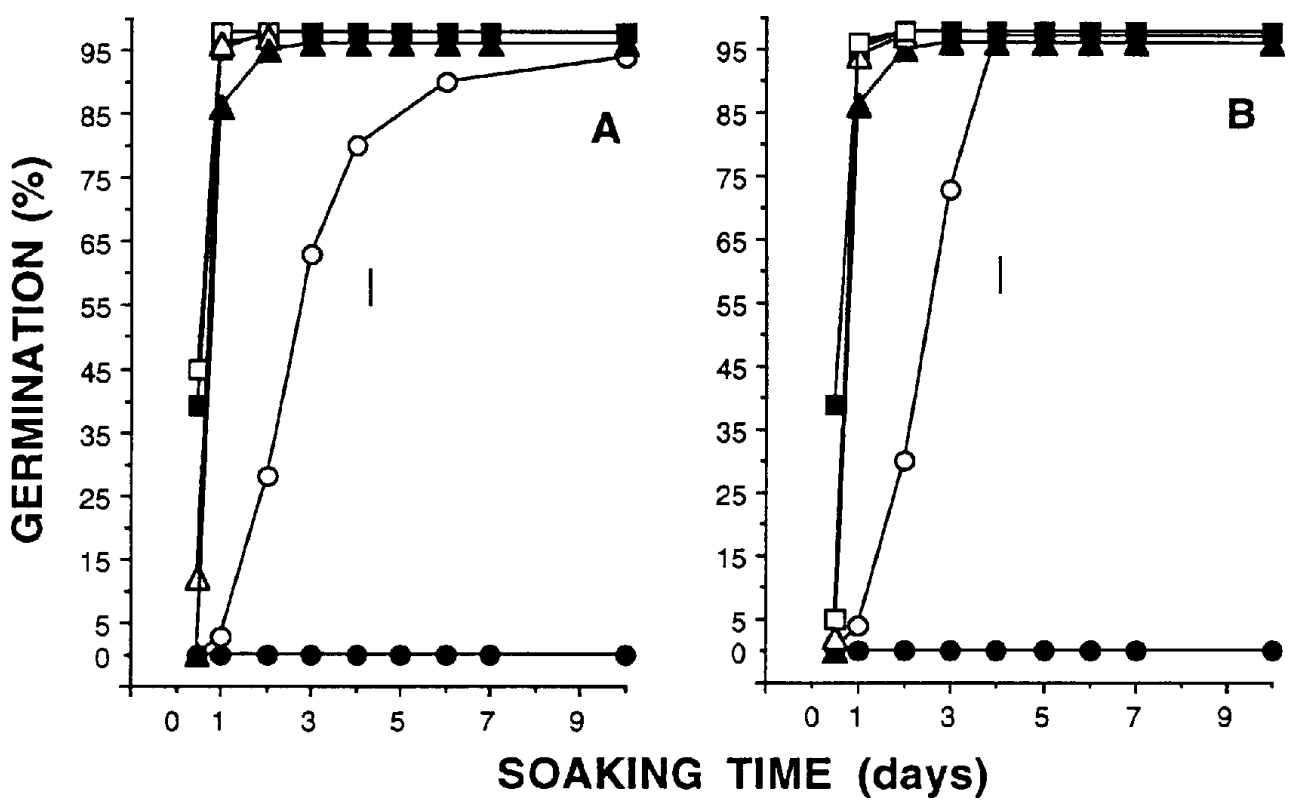

Fig. 3. Comparative effects of tetcyclacis (TCY) and ABA on dormancy induction in 'Montello' lettuce seeds and its release by (A) irradiation and (B) GA 4t+7. $_{\text {. }}$ After a 24-h presoak in darkness in $50 \mu \mathrm{M} \mathrm{TCY}$ or $50 \mu \mathrm{M} \mathrm{ABA}$, the seeds were washed, dried, and germinated (A) in water in light or darkness and (B) in water or 1 mM GA ${ }_{4+7}$ in darkness at 25C. Legends in A: germinated in water in light ( $\square)$, germinated in water in dark $(\mathbf{\square})$, presoaked in TCY then germinated in water in light $(O)$, presoaked in TCY then germinated in water in dark $(\bullet)$, presoaked in ABA then germinated in water in light $(\Delta)$, presoaked in ABA then germinated in water in dark $(\mathbf{\Delta})$. Legends in B: germinated in water $(\mathbf{\square})$, germinated in GA $(\mathbf{\square})$, presoaked in TCY then germinated in water $(\bullet)$, presoaked in TCY then germinated in GA $(O)$, presoaked in ABA then germinated in water $(\boldsymbol{\Delta})$, presoaked in ABA then germinated in GA $(\Delta)$. Bars indicate $\mathrm{LSD}_{0.05}$.

Table 1. Release of tetcyclacis-induced (TCY) dormancy ${ }^{\mathrm{z}}$ in seeds of lettuce cultivars by white light.

\begin{tabular}{lccc}
\hline \hline & & \multicolumn{2}{c}{ Germination $(\%)^{\mathrm{y}}$} \\
\cline { 3 - 4 } Cultivar & TCY $(\mu \mathrm{M})$ & Dark & Light \\
\hline Grand Rapids & $5 \mu \mathrm{M}$ & $0(35)^{\mathrm{x}}$ & $98(99)$ \\
Emperor & $50 \mu \mathrm{M}$ & $6(99)$ & $99(100)$ \\
Ithaca & $50 \mu \mathrm{M}$ & $13(97)$ & $96(98)$ \\
Garnet & $5 \mu \mathrm{M}$ & $0(0)$ & $85(99)$ \\
Montello & $50 \mu \mathrm{M}$ & $5(96)$ & $94(98)$ \\
Empress & $50 \mu \mathrm{M}$ & $0(97)$ & $97(97)$ \\
Mesa 659 & $50 \mu \mathrm{M}$ & $0(98)$ & $93(98)$ \\
LSD $_{0.05}$ & & $3(2)$ & $4(2)$
\end{tabular}

${ }^{\mathrm{z}}$ Dormancy was induced by a $24-\mathrm{h}$ dark soak in 5 or $50 \mu \mathrm{M}$ TCY at $25 \mathrm{C}$, followed by washing and drying in darkness at the same temperature.

y'Dormant seeds were germinated in water at $25 \mathrm{C}$ in light or darkness for 10 days.

${ }^{x}$ Data in parentheses are germination percentages of seeds not treated with

FGble 2. Release of tetcyclacis induced dormancy ${ }^{\mathrm{z}}$ in seeds of lettuce cultivars by $1 \mathrm{mM} \mathrm{GA}_{4+7}$.

\begin{tabular}{lcc}
\hline \hline & \multicolumn{3}{c}{ Dark germination $(\%)^{\mathrm{y}}$} \\
\cline { 2 - 3 } Cultivar & $-\mathrm{GA}_{4+7}$ & $+\mathrm{GA}_{4+7}$ \\
\hline Grand Rapids $(5 \mu \mathrm{M})$ & 0 & 98 \\
Emperor $(50 \mu \mathrm{M})$ & 3 & 100 \\
Ithaca $(50 \mathrm{mM})$ & 6 & 97 \\
Garnet $(5 \mu \mathrm{M})$ & 0 & 93 \\
Montello $(50 \mu \mathrm{M})$ & 6 & 96 \\
Empress $(50 \mu \mathrm{M})$ & 0 & 86 \\
Mesa $659(50 \mu \mathrm{M})$ & 0 & 88 \\
LSD $_{0.05}$ & 2 & 3 \\
\hline Dormancy & 0 &
\end{tabular}

$\overline{{ }^{\mathrm{Z}} \text { Dormancy induction by TCY, washing and drying of seeds were as in }}$ Table 1.

yDormant seeds were germinated in water or $1 \mathrm{mM} \mathrm{GA}_{4+7}$ at $25 \mathrm{C}$ in darkness for 14 days.
Table 3. Release of tetcyclacis induced dormancy ${ }^{\mathrm{z}}$ in seeds of lettuce cultivars by moist-chilling.

\begin{tabular}{lcc}
\hline \hline & \multicolumn{2}{c}{ Dark germination (\%) } \\
\cline { 2 - 3 } Cultivar & Dormant (before chilling) & Chilled $^{\mathrm{y}}$ \\
\hline Grand Rapids (6 days) & 0 & 90 \\
Emperor (2 days) & 6 & 92 \\
Ithaca (10 days) & 3 & 90 \\
Garnet (6 days) & 0 & 96 \\
Montello (10 days) & 6 & 85 \\
Empress (6 days) & 0 & 97 \\
Mesa 659 (5 days) $_{\text {LSD }_{0.05}}$ & 0 & 93 \\
\hline
\end{tabular}

$\overline{{ }^{\mathrm{z}} \text { Dormancy induction, concentration of tetcyclacis used for each cultivar, }}$ washing and drying were as in Table 1.

yDormant seeds were moist-chilled at $5 \mathrm{C}$ in darkness and germinated in water at $25 \mathrm{C}$ for 7 days.

${ }^{x}$ Numbers in parentheses for each cultivar are days moist-chilled at $5 \mathrm{C}$.

Table 4. Induction of dormancy ${ }^{\mathrm{z}}$ in 'Mesa 659' lettuce seeds by paclobutrazol (PL), ancymidol (AL), and flurprimidol (FP) and its release by $\mathrm{GA}_{4+7}$, irradiance, and moist-chilling.

\begin{tabular}{lcccc}
\hline & \multicolumn{4}{c}{ Germination $(\%)^{\mathrm{y}}$} \\
\cline { 2 - 5 } Treatment & Dark & Dark + GA & Light & Chilled \\
\hline $\mathrm{AL}, 200 \mu \mathrm{M}$ & 2 & 84 & 96 & Not tested \\
$\mathrm{PB}, 100 \mu \mathrm{M}$ & 4 & 100 & 100 & 98 \\
$\mathrm{FP}, 100 \mu \mathrm{M}$ & 4 & 90 & 98 & Not tested \\
$\mathrm{LSD}_{0.05}$ & 1 & 3 & 2 & Not tested \\
\hline
\end{tabular}

${ }^{\mathrm{Z}}$ Dormancy induction, washing and drying were as in Table 1.

yDormant seeds were germinated for 10 days at $25 \mathrm{C}$ in water in darkness, in $1 \mathrm{mM} \mathrm{GA}_{4+7}$ in darkness, in water in light, and in water in darkness after 5 days moist-chilling at $5 \mathrm{C}$. 


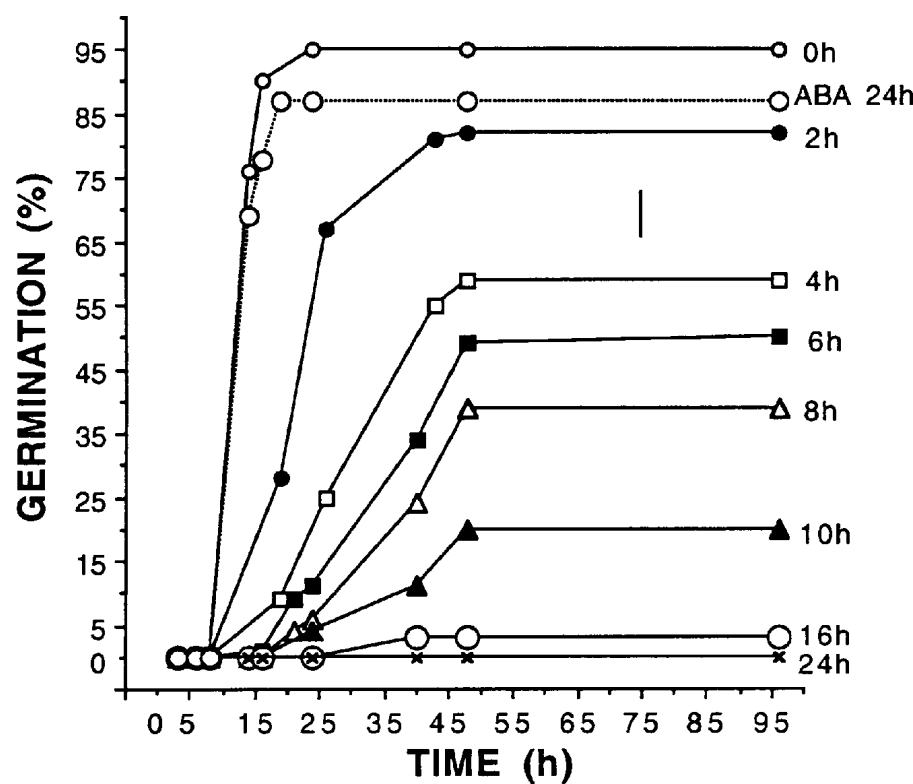

Fig. 4. Effect of presoaking 'Mesa 659' lettuce seeds in tetcyclacis solution for various periods on induction of dormancy. Seeds were soaked in darkness at $25 \mathrm{C}$ in $50 \mu \mathrm{M}$ tetcyclacis for 0 to $24 \mathrm{~h}$ or in $50 \mu \mathrm{M} \mathrm{ABA}$ for $24 \mathrm{~h}$, washed, dried, and germinated in water at $25 \mathrm{C}$ in darkness. Bar indicates $\mathrm{LSD}_{0.05}$.

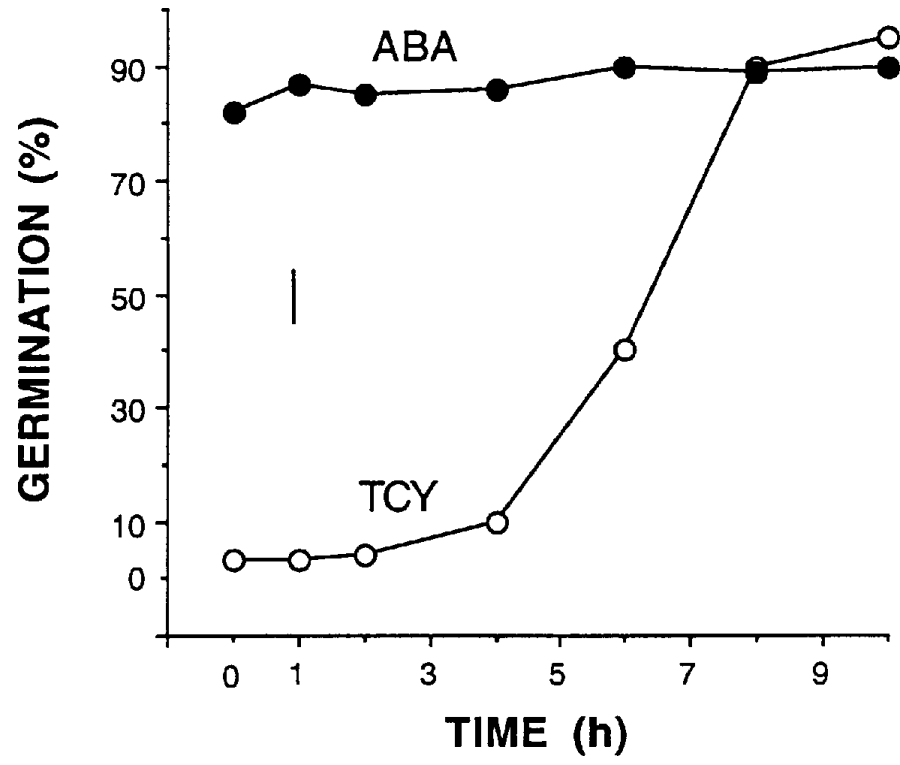

Fig. 5. Effectiveness of tetcyclacis (TCY) and ABA to induce dormancy in 'Emperor' lettuce seeds following presoaking of seeds in water for various periods. Seeds were soaked in water for up to $10 \mathrm{~h}$ in darkness at $25 \mathrm{C}$, transferred to $50 \mu \mathrm{M} \mathrm{TCY}$ or $50 \mu \mathrm{M} \mathrm{ABA}$ for $24 \mathrm{~h}$ in darkness at $25 \mathrm{C}$, and then washed, and germinated in water at $25 \mathrm{C}$ in darkness for 10 days. Bar indicates $\mathrm{LSD}_{0.05}$.

tetcyclacis as fewer seeds germinated upon transfer to water (Fig. 4). After a 10 -h soak, about $80 \%$ seeds were rendered dormant, and after 16- to 24 -h dormancy was induced in $95 \%$ to $100 \%$ seeds. Unlike tetcyclacis, a soak in $50 \mu \mathrm{M}$ ABA for $24 \mathrm{~h}$ failed to induce dormancy as the seeds germinated readily upon washing.

To determine if any discrete point during imbibition was critical for inducing dormancy, tetcyclacis was applied to lettuce seeds at various times of soaking in water. Dormancy was induced completely by tetcyclacis applied to seeds presoaked for up to $4 \mathrm{~h}$ in water and partly in seeds presoaked for $6 \mathrm{~h}$ (Fig. 5). After 8-h soak nearly all seeds germinated, implying that GA synthesized during this period was critical to preventing dormancy induction by tetcyclacis. At no time during the $10-\mathrm{h}$ presoak was ABA able to
Table 5. Comparative effects of tetcyclacis (TCY) and ABA on dormancy induction in 'Emperor' lettuce seeds and its prevention by $\mathrm{GA}_{4+7}$.

\begin{tabular}{|c|c|c|c|}
\hline \multirow[b]{2}{*}{ Treatment $^{\mathrm{z}}$} & \multicolumn{2}{|c|}{ Germination/100 seeds ${ }^{\mathrm{y}}$} & \multirow{2}{*}{$\begin{array}{c}\text { Total } \\
\text { germination } \\
(\%)\end{array}$} \\
\hline & $\begin{array}{l}\text { During initial } \\
\text { soak }\end{array}$ & $\begin{array}{c}\text { After } \\
\text { washing }\end{array}$ & \\
\hline TCY & 2 & 4 & 6 \\
\hline $\mathrm{TCY}+\mathrm{GA}_{4+7}$ & 85 & 12 & 97 \\
\hline $\mathrm{ABA}$ & 0 & 90 & 90 \\
\hline $\mathrm{ABA}+\mathrm{GA}_{4+7}$ & 0 & 98 & 98 \\
\hline $\mathrm{LSD}_{0.05}$ & 4 & 6 & 3 \\
\hline
\end{tabular}

${ }^{2}$ Seeds were soaked at $25 \mathrm{C}$ for $24 \mathrm{~h}$ in darkness in $50 \mu \mathrm{M}$ TCY and $50 \mu \mathrm{M}$ ABA, with or without $1 \mathrm{~mm} \mathrm{GA}_{4+7}$.

${ }^{y}$ Seeds that germinated during initial 24-h soak were counted. Remaining nongerminated seeds were washed, dried, and germinated in water for 48 $\mathrm{h}$ at $25 \mathrm{C}$ in darkness.

Table 6. Comparative effects of tetcyclacis (TCY) and ABA on dormancy induction in 'Mesa 659' lettuce seeds during osmotic soak, its prevention by simultaneous application of $\mathrm{GA}_{4+7}$, and the release of TCYinduced dormancy by $\mathrm{GA}_{4+7}$.

\begin{tabular}{lcc}
\hline \hline & \multicolumn{2}{c}{ Germination $(\%)^{\mathrm{y}}$} \\
\cline { 2 - 3 } Osmotic soak $^{\mathrm{z}}$ & Water & $\mathrm{GA}_{4+7}$ \\
\hline PEG & 96 & 99 \\
PEG + TCY & 6 & 99 \\
PEG + ABA & 90 & 98 \\
PEG+ TCY + GA & 98 & 97 \\
LSD $_{0.05}$ & 4 & 1
\end{tabular}

ZTwo-day osmotic soak in darkness at 25C in-1.2 MPa PEG solution, with or without $50 \mu \mathrm{M}$ TCY, $50 \mu \mathrm{M} \mathrm{ABA}$, and $50 \mu \mathrm{M}$ TCY plus $1 \mathrm{mM} \mathrm{GA}_{4+7}$. ${ }^{y}$ After osmotic soak, seeds were washed and germinated in water or $1 \mathrm{~mm}$ $\mathrm{GA}_{4+7}$ in darkness for 6 days at $25 \mathrm{C}$.

Table 7. Comparative effects of tetcyclacis (TCY) and ABA on dormancy induction in 'Mesa 659' letuce seeds at $5 \mathrm{C}$, its prevention by $\mathrm{GA}_{4+7}$, and the release of induced dormancy by $\mathrm{GA}_{4+7}$ or irradiation.

\begin{tabular}{lccc}
\hline \hline & \multicolumn{3}{c}{$\%$ Germination } \\
\cline { 2 - 4 } Soak at $5 C^{\mathrm{z}}$ & Dark & Light & Dark + GA $_{4+7}$ \\
\hline TCY & 9 & 95 & 95 \\
ABA & 97 & 98 & 98 \\
TCY + GA & 85 & 98 & 96 \\
LSD $_{0.05}$ & 4 & 2 & 2
\end{tabular}

${ }^{\mathrm{z}}$ Seeds were soaked for $24 \mathrm{~h}$ at $5 \mathrm{C}$ in darkness with $50 \mu \mathrm{M} \mathrm{TCY}, 50 \mu \mathrm{M}$ $\mathrm{ABA}$, and $50 \mu \mathrm{M}$ TCY plus $1 \mathrm{~mm} \mathrm{GA}_{4+7}$.

${ }^{\mathrm{y}}$ Following the $5 \mathrm{C}$ soak treatment, seeds were washed in darkness and germinated at $25 \mathrm{C}$ in water in darkness, in water in light, or in $1 \mathrm{~mm} \mathrm{GA}_{4+7}$ in darkness for 6 days.

induce dormancy.

Prevention of dormancy induction by $\mathrm{GA}_{4+7}$ in lettuce seeds under favorable and unfavorable conditions. In 'Emperor' lettuce seeds soaked simultaneously in tetcyclacis and $\mathrm{GA}_{4+7}$ for $24 \mathrm{~h}$ at $25 \mathrm{C}$ (a favorable condition for germination), the dormancy induction was prevented by $\mathrm{GA}_{4+7}$, as the majority of seeds (85\%) germinated during the initial soak, and a few after washing (Table 5). Dormancy was not induced by ABA even though it inhibited germination during the initial soak. Tetcyclacis also induced dormancy in 'Mesa 659' lettuce seeds during an osmotic (Table 6) or 5C (Table 7) soak (unfavorable conditions for germination), and the dormancy induction was prevented by $\mathrm{GA}_{4+7}$; in these cases, the counteractive effect of simultaneous application of $\mathrm{GA}_{4+7}$ and 
Table 8. Effect of fluridone (FL) applied in the presence or absence of ABA or tetcyclacis (TCY) during thermodormancy induction in 'Mesa 659' and 'Emperor' lettuce seeds.

\begin{tabular}{|c|c|c|c|}
\hline \multirow[b]{2}{*}{ Soak at $35 C^{z}$} & \multicolumn{3}{|c|}{ Germination at $25 \mathrm{C}(\%)^{\mathrm{y}}$} \\
\hline & Mesa 659 & & Emperor \\
\hline Untreated (0-h soak at $35 \mathrm{C})$ & 99 & & 98 \\
\hline Water & 3 & & 13 \\
\hline $\mathrm{ABA}$ & 7 & & 4 \\
\hline FL & 99 & & 96 \\
\hline $\mathrm{ABA}+\mathrm{FL}$ & 97 & & 100 \\
\hline TCY & --- & & 2 \\
\hline $\mathrm{TCY}+\mathrm{FL}$ & --- & & 98 \\
\hline $\mathrm{LSD}_{0.05}$ & 4 & & 6 \\
\hline \multicolumn{4}{|c|}{$\begin{array}{l}{ }^{\mathrm{z}} \text { Seeds were soaked for } 48 \mathrm{~h} \text { in darkness at } 35 \mathrm{C} \text { in } 22.5 \mu \mathrm{M} \text { FL, } 100 \mu \mathrm{M} \\
\mathrm{ABA}, 50 \mu \mathrm{M} \text { TCY, or combinations thereof. } \\
\text { y After } 35 \mathrm{C} \text { soak, seeds were washed and germinated in water for } 6 \text { days } \\
\text { in darkness. }\end{array}$} \\
\hline \multicolumn{4}{|c|}{$\begin{array}{l}\text { Table 9. Dormancy induction by tetcyclacis (TCY) in seeds of pepper } \\
\text { tomato, onion, carrot, and the effectiveness of } \mathrm{GA}_{4+7} \text { and light to } \\
\text { release the dormancy. }\end{array}$} \\
\hline \multirow{2}{*}{ Seed/TCY soak ${ }^{\mathrm{z}}$} & \multicolumn{3}{|c|}{ Germination $(\%)^{\mathrm{y}}$} \\
\hline & Dark & Dark + GA & Light \\
\hline Tomato, $50 \mu \mathrm{M}$ & $8(98)^{x}$ & 96 & $6(97)$ \\
\hline Pepper , $50 \mu \mathrm{M}$ & $2(96)$ & 98 & $3(95)$ \\
\hline Carrot, $10 \mu \mathrm{M}$ & $0(85)$ & 88 & $0(84)$ \\
\hline Onion, $50 \mu \mathrm{M}$ & $35(96)$ & 95 & $40(93)$ \\
\hline Celery , $10 \mu \mathrm{M}$ & $0(0)$ & 10 & $2(76)$ \\
\hline Impatiens, $50 \mu \mathrm{M}$ & $0(75)$ & --- & $80(81)$ \\
\hline $\mathrm{LSD}_{0.05}$ & $7(6)$ & 5 & $6(7)$ \\
\hline
\end{tabular}

${ }^{\mathrm{z}}$ Seeds were soaked in TCY solutions ( 10 or $\left.50 \mu \mathrm{M}\right)$ at $25 \mathrm{C}$ (except celery which was soaked at 20C) for $24 \mathrm{~h}$ in darkness, followed by washing and drying as in Table 1.

yDormant seeds were germinated at 25C (except celery seeds which were germinated at 20C) in water in darkness, in water in light, and in $1 \mathrm{~mm}$ $\mathrm{GA}_{4+7}$ in darkness for 10 days.

${ }^{\mathrm{x}}$ Data in parentheses are germination percentages of seeds not treated with TCY.

tetcyclacis was expressed after a transfer of the seeds to water at $25 \mathrm{C}$. The data also show that dormancy induced by tetcyclacis can be released by irradiation or $\mathrm{GA}_{4+7}$ applied after the removal of tetcyclacis by washing. Unlike tetcyclacis, ABA failed to induce dormancy when applied during favorable (25C) or unfavorable conditions (reduced $\psi$ or at $5 \mathrm{C}$ ) for germination.

Effect of fluridone on thermodormancy induction in lettuce seeds. Thermodormancy was induced in both 'Mesa' and 'Emperor' lettuce seeds soaked at $35 \mathrm{C}$ for $48 \mathrm{~h}$ in darkness, as the seeds failed to germinate upon transfer to $25 \mathrm{C}$ in darkness (Table 8). Addition of fluridone during the 48-h soak at $35 \mathrm{C}$ prevented the thermodormancy induction in both cultivars. However, neither ABA nor tetcyclacis counteracted the dormancy-preventing effect of fluridone.

Dormancy induction and release in seeds besides lettuce. Dormancy was also induced in tomato, pepper, carrot, onion, impatiens, and celery seeds to varying degrees with tetcyclacis (Table 9) as well as other GA synthesis inhibitors (not shown). Impatiens seeds behaved like lettuce as dormancy induced by 50 $\mu \mathrm{m}$ tetcyclacis was released on exposure to light. Unlike lettuce, dormancy induced in carrot, tomato, pepper, and onion seeds was not released by either light or by moist-chilling at $5 \mathrm{C}$ (data not shown), but was released by $\mathrm{GA}_{4+7}$. Celery seeds used were dormant in darkness but not in light. Tetcyclacis intensified the dormancy as the responsiveness of seeds to light or $\mathrm{GA}_{4+7}$ (untreated celery seeds germinated $80 \%$ in $1 \mathrm{~mm} \mathrm{GA}_{4+7}$ in darkness) was reduced.

\section{Discussion}

The studies show that GA biosynthesis inhibitors induce dormancy in seeds of several genera and species. Dormancy is released by $\mathrm{GA}_{4+7}$, suggesting that the amount of GA synthesized during soaking may determine dormancy induction and release. That dormancy induced by GA synthesis inhibitors could be released also by light and moist-chilling (e.g., in lettuce seeds), factors that mimic the GA effect, further supports the involvement of GA in dormancy prevention and release. Tetcyclacis, paclobutrazol, ancymidol, and flurprimidol inhibit oxidative steps from ent-kaurene to ent-kaurenoic acid in the gibberellin pathway and are known to retard cellular elongation (Rademacher, 1991). Thus, the dormancy-inducing action of these inhibitors may be related to a block of GA-mediated processes controlling cellular elongation.

The inhibitors, tetcyclacis and paclobutrazol, were more effective in darkness than in light in inhibiting germination and inducing dormancy in lettuce seeds. Also, the dormancy-inducing effect of these inhibitors was reversed by GA, irradiation, and moistchilling. Synthesis of GA may occur during or subsequent to irradiation and moist-chilling. It is also possible that the sensitivity of the receptor sites to GA, modulating induction, and release of dormancy, is enhanced by moist-chilling and light in a similar fashion. In either case, the need for GA for dormancy release would be diminished. Moist-chilling and GA treatments are reported to enhance the sensitivity of seeds to light (Rethy et al., 1987; VanDerWoude, 1989). Also, the sensitivity of lettuce seeds to GA decreases as the temperature increases, requiring higher GA concentrations to release dormancy or promote germination in darkness (Khan, 1968; Takeba and Matsubara, 1979). Thus, the GA requirement for the prevention and release of dormancy may be governed by changes in seed environment.

Unlike tetcyclacis, ABA failed to induce dormancy in lettuce seeds soaked in the dark at $5 \mathrm{C}, 25 \mathrm{C}$, or during low $\psi$ seedhydration treatment. Noninduction of dormancy by ABA cannot be attributed to lack of ABA penetration because ABA strongly inhibits seed germination (Khan, 1968; see also Table 5). Only when ABA is removed by washing is its effect nullified or considerably reduced. Compared to a more permanent effect of GA synthesis inhibitors, effect of ABA is transient and probably not directly related to dormancy induction.

Although fluridone, which is regarded as indirectly influencing ABA production (Le Page-Degivry and Garello, 1992), prevented thermodormancy induction in lettuce seeds soaked at $35 \mathrm{C}$, the dormancy-preventing effect of fluridone was not counteracted by $\mathrm{ABA}$. It is not known if ABA is produced during thermo-inhibition and that fluridone action is related to a decrease in ABA level. There are several recent reports correlating increased ABA production with its inhibitory effect on germination or growth processes (Karssen et al., 1989; Le Page-Degivry and Garello, 1992). However, these do not constitute definitive evidence for regarding $\mathrm{ABA}$ as a dormancy factor. In immature embryos of sunflower, fluridone treatment decreased the level of $\mathrm{ABA}$ and improved the germination, but ABA treatment itself was ineffective in inducing dormancy as the embryos germinated upon removal of ABA (Le Page-Degivry and Garello, 1992). In addition to inhibiting ABA production, fluridone appears to interfere with tetcyclacis action 
(Table 8). Thus, considerable caution is needed in interpreting results using fluridone.

Gibberellic acid appears to be synthesized quite early during 25C soak of lettuce seeds. When 'Mesa 659' lettuce seeds were soaked directly in tetcyclacis, nearly $80 \%$ of the seeds became dormant after $10 \mathrm{~h}$ soak (Fig. 4). When tetcyclacis was applied following different periods of water soak, the seeds escaped from the dormancy-inducing effect of tetcyclacis at $\approx 8 \mathrm{~h}$ (Fig. 5). Thus, a period of 8 to $10 \mathrm{~h}$ is critical for inducing dormancy and can be regarded as the dormancy-sensitive phase of imbibition. During this period, GA is probably synthesized, allowing the seed to prevent dormancy induction. As ABA did not induce dormancy in seeds following various periods of water presoak, its action might be unrelated to dormancy induction.

Previous studies with GA synthesis inhibitors were conducted in the context of germination (radicle protrusion). No serious attempts have been made to separate germination inhibition from dormancy induction and dormancy release or prevention from germination promotion. There is sufficient documentation that dormancy induction and release are reversible processes and can operate independently of germination (usually radicle protrusion), which is irreversible (Khan and Karssen, 1980; Khan and Zeng, 1985; Khan and Andreoli, 1992). The release or prevention of dormancy by GA or other factors, such as respiratory inhibitors, moist-chilling, and irradiation, need not manifest itself in actual germination if conditions are not right for germination (Khan and Zeng, 1985; Khan and Andreoli, 1992, see also Table 6 and 7). Thus, it seems that there is no need for GA, irradiation, or moistchilling for germination of seeds (such as lettuce) once the dormancy release has been accomplished or its induction prevented. These seeds will germinate readily in darkness in absence of GA or irradiation under suitable germination conditions.

The mechanism of dormancy induction by GA biosynthesis inhibitors may differ in different seeds. In lettuce and perhaps other light-requiring seeds, changes in embryo growth potential may be associated with dormancy induction and release (Khan and Samimy, 1982). Dormancy prevention or release may be mediated by GAstimulated activities of hydrolytic enzymes resulting in the production of osmotically active substances that lower the cellular $\psi$, improve water uptake, and increase embryo growth potential.

In tomato, pepper, carrot, and onion seeds, dormancy was induced equally well in light and darkness by GA synthesis inhibitors. The state of the endosperm surrounding the embryo seems to determine dormancy in pepper, tomato, and carrot. The GA-deficient mutant seeds of tomato, lacking the ability to synthesize GA, fail to produce endo- $\beta$-mannanase and other enzymes needed for the removal of endosperm barrier essential for germination (Groot et al., 1988). A similar mechanism might operate in pepper seeds (Watkins et al., 1985).

\section{Literature Cited}

Cathey, H. M. 1964. Physiology of growth retarding chemicals. Annu. Rev. Plant Physiol. 15:271-302.

Coolbaugh, R.C., S.S. Hirano, and C.A. West. 1978. Studies on the specificity and site of action of $\alpha$-cyclopropyl- $\alpha$-[p-methoxyphenyl]-5pyrimidine methyl alcohol (ancymidol), a plant growth regulator. Plant Physiol. 62:571-576.

Gardner, G. 1983. The effect of growth retardants on phytochromeinduced lettuce seed germination. J. Plant Growth Regulat. 2:159-163. Groot, S.P.C., E. Kieliszewska-Rokicka, E. Vermeer, and C.M. Karssen.
1988. Gibberellin induced hydrolysis of endosperm cell walls in gibberellin deficient tomato seeds prior to radicle protrusion. Planta 174:500 604.

Izumi, K., I. Yamaguchi, A. Wada, H. Oshio, and N. Takahashi. 1984. Effects of a new plant growth retardant $(E)$-1-(4-chlorophenyl)-4,4dimethyl-2-(1,2,4-triazol-1-yl)-penten-3-ol (S-3307) on the growth and gibberellin content of rice plants. Plant Cell Physiol. 25:611-617.

Jung, J.W, H. Koch, N. Rieber, and B. Wurzer. 1980. Zur wachtums regulierenden Wirkung von Triazolin- und Aziridinderivaten des Norbornenodiazetins. J. Agron. and Crop Sci. 149:128-136.

Jung, J. and W. Rademacher. 1983. Plant growth regulating chemicalscereal grains, p. 253-271. In: L.G Nickell (ed.). Plant growth regulating chemicals. vol. 1. CRC Press, Boca Raton, Fla.

Karssen, C.M,S. Zagorski, J. Kepczynski, and S.P.C. Groot. 1989. Key role for endogenous gibberellins in the control of seed germination. Ann. Bot. 63:71-80.

Khan, A.A. 1968. Inhibition of gibberellic acid-induced germination by abscisic acid and reversal by cytokinins. Plant Physiol. 43:1463-1465.

Khan, A.A. 1971. Cytokinins: Permissive role in seed germination. Science 171:853-859.

Khan, A.A. and C. Andreoli. 1993. Hormonal control of seed dormancy and germination under stressful and nonstressful conditions, p. 625632. In: D. Come and F. Corbineau (eds.). Fourth international workshop on seeds. vol. 2. Angers, France. Association pour la formation professionelle de l'interprofession semences, Paris.

Khan, A.A. and C.M. Karssen. 1980. Induction of dormancy in Chenopodium bonus-henricus L. seeds by osmotic and high temperature treatments and its prevention by light and growth regulators. Plant Physiol. 66:175-181.

Khan, A.A. and C. Samimy. 1982. Hormones in relation to primary and secondary seed dormancy, p. 203-241. In: A.A. Khan (ed.). The physiology and biochemistry of seed development, dormancy and germination. Elsevier Biomedical Press, Amsterdam.

Khan, A.A. and G.W. Zeng. 1985. Dual action of respiratory inhibitors: Inhibition of germination and prevention of dormancy induction in lettuce seeds. Plant Physiol. 77:817-825.

Le Page-Degivry, M.T. and C. Garello. 1992. In situ abscisic acid synthesis. Plant Physiol. 98:1386-1390.

Lever, B.G., S.J. Shearing, and J.J. Batch. 1982. British crop protection conference-Weeds. vol. 1. British Crop Protection Council, Croydon, England.

Nambara, E., T. Akazawa, and P. McCourt. 1991. Effects of the gibberellin biosynthetic inhibitor uniconazol on mutants of Arabidopsis. Plant Physiol. 97:736-738.

Rademacher, W. 1991. Biochemical effects of plant growth retardants, p. 169-200. In: H.W. Gausman (ed.). Plant biochemical regulators. Mercel Dekker, New York.

Rethy, R., A. Dedonder, E. De Petter, L. Van Wiemeersch, H. Fredericq, J. De Greef, H. Stevaert, and H. Stevens. 1987. Biphasic fluenceresponse curves for phytochrome-mediated Kalanchoe seed germination sensitized by gibberellic acid. Plant Physiol. 83:126-130.

Samimy, C. and A.A. Khan. 1983. Secondary dormancy, growth regulator effects and embryo growth potential in curly dock (Rumex crispus) seeds. Weed Sci. 31:153-158.

Shive, J.B. and H.D. Sisler. 1976. Effects of ancymidol (a growth retardant) and triarimol (a fungicide) on the growth, sterols, and gibberellins of Phaseolus vulgaris (L.). Plant Physiol. 57:640-644.

Takeba, G. and S. Matsubara. 1979. Measurement of growth potential of the embryo in New York lettuce seed under various combinations of temperature, red light and hormones. Plant Cell Physiol. 51:51-61.

VanDerWoude, W. 1989. Phytochrome and sensitization in germination control, p. 181-189. In: R.B. Taylorson (ed.). Recent Advances in the Development and Germination of Seeds. Plenum Press, New York.

Watkins, J.T., D.J. Cantliffe D.J., D.J. Huber, and T.A. Nell. 1985. Gibberellic acid stimulated degradation of endosperm in pepper. $\mathrm{J}$ Amer. Soc. Hort. Sci. 110:61-65. 